\title{
FROM STAR WARS TO SPACE WARS-THE NEXT STRATEGIC FRONTIER: PARADIGMS TO ANCHOR SPACE SECURITY
}

\author{
Jackson Nyamuya Maogoto* and Steven Freeland ${ }^{* *}$
}

\begin{abstract}
Military blueprints by major space-faring powers now encapsulate concepts of 'space support' and 'force enhancement' which point to a central role of space assets in facilitating military operations while notions of 'space control' and 'force application' suggest the weaponization of space, and the putative view that space may in the near future be a theatre of military operations. As defence goals increasingly focus on space as the final frontier evident in development of national missile defence systems, anti-satellite weapons and other space-based systems, international peace and security faces a new challenge. Creators of the current legal regime for space failed to foresee the rapid rate at which technological and engineering breakthroughs would take place. Now the shortcomings in the current regime beg the question of how the law can keep up and address space technology. It is imperative that the international community act now rather than later. In light of the existing lacunae in the international space law regime, this Article seeks to explore avenues/paradigms through which the militarization of space may be regulated and its weaponization addressed.
\end{abstract}

\subsection{INTRODUCTION}

The increasing militarization and weaponization of outer space poses difficult legal questions and also represents a clear and present danger to international peace and security. There is already a fear of an arms race being undertaken in space, with the latest developments in Washington, Moscow and Beijing adding further fuel to that fire. With the world's major powers increasingly reliant for their security on space assets, Russia and China are keen to cement their place as space superpowers as counterweights to the United States ('US'). China, in particular, has in recent

\footnotetext{
* LL.B (Hons) (Moi), LL.M (Hons) (Cantab), LL.M (UTS), PhD (Melb), GCertPPT (UoN), Senior Lecturer in International Law, University of Newcastle (Australia).

** Associate Professor in International Law, University of Western Sydney (Australia); Visiting Professor of International Law, University of Copenhagen, (Denmark); Member of the Space Law Committee of the International Law Association; Member of the International Institute of Space Law.

The authors acknowledge the incisive and enlightening comments of Professor Peter H. Van Fenema-McGill University, that broadened and strengthened the central themes of this Article enhancing its substantive breadth and structural depth. Any errors however remain the authors'.
} 
years been concentrating on the development of military space assets and a leaner and efficient technologically driven military.

The effect of the initiatives by the US, Russia and China has been negative, since the net result has been to spur Europe to also re-examine the role of space in its defense policy. The old arms race dynamic appears to be reasserting itself, partly as a result of the increasing pace of the military activities of the major space powers but also as a result of the implementation of a European Security and Defense Policy. ${ }^{1}$ With increased security requirements and the important role of space technology, the pressure is on the European Space Agency (ESA) to re-define its role and future contribution to European defense and security. ${ }^{2}$ The most striking development is that ESA, which has traditionally been committed to peaceful uses rather than seeking to stop the emerging space arms competition, is instead joining the race. ${ }^{3}$

The creators of the current international legal regime for space could not have foreseen the rapid rate at which technological advancements and breakthroughs would take place. The shortcomings in the applicable legal principles beg the question of whether the Space Law regime can keep up with technology. While for almost its entire history, the United Nations ('UN') in general, and the Security Council in particular, have approached their mission in a reactive manner, this stance has become untenable in the face of a determined push by space-faring powers to not only

\footnotetext{
${ }^{1}$ Presidency Conclusions-Presidency Report on the European Security and Defence Policy, 4 December 2000, Dep 01/185; Nicole Gnesotto, ed., EU SECURITY AND DEFENCE POLICY_THE FIRST FIVE YEARS (1999-2004) (2004). For background information see UK Library Research Papers 00/20, European Defence: From Pörtschach to Helsinki, 21 February 2000 and 00/84, Common European Security and Defence Policy: A Progress Report, 31 October 2000 available at http://www.parliament.uk/commons/lib/research (last visited Oct. 14, 2007).

${ }^{2}$ An international report on space and security policy in Europe, issued in autumn 2003, starts out by stating that Space is a strategic asset. ESA und Istituto Affari Internatzionali:, International Report on Space and Security Policy in Europe, November 2003.

${ }^{3}$ ESA Strategy Department, Agenda 2007 - A Document by the ESA Director General, Noordwijk, October 2003 available at http://esamultimedia.esa.int/docs/BR-213.pdf (last visited Oct. 14, 2007)
} 
dominate but also to control space as a battle frontier. As strategic defense goals increasingly focus on the development of national missile defense systems, involving ground-based defense and space-based systems, the international community must rise to these challenging issues in the interests of maintaining international peace and security, a fundamental purpose of the United Nations. ${ }^{4}$ An arms race in space will inevitably lead to a situation where peace and security is seriously eroded and an atmosphere of insecurity is generated.

The central theme of this Article is that the weaponization of space and its evolution into a distinct theatre of military operations seems likely, given the reliance on space systems and the increasing militarization of space. The Article is premised on the reality that there will be a serious legal deficit in the absence of specific international norms restricting the possibility of outer space becoming a direct battlefield. In light of this reality, the Article will explore and articulate new paradigms that may contribute to the prevention of an arms race in outer space and thus enhance the capacity of the international community to deal with a phenomenon which has moved from fantasy to likelihood.

\subsection{CLEAR \& PRESENT DANGER? CONTEMPORARY DEVELOPMENTS-ARMS (UN)LIMITATION}

With major space-faring powers focusing on military aspects of space in force enhancement, a consideration of the issue of space weaponization has moved far from the once theoretical discussion debated by the early founders of the current international space law regime. Currently the US is spending billions of dollars in the research and development of advanced space

\footnotetext{
${ }^{4}$ See Charter of the United Nations, article 1(1).
} 
weapons, with its military establishment resolute that the dominance and control of space is a necessity.

In a similar vein, many senior political and military leaders in the other three major space-faring powers - Russia, Europe and China - have called for the allocation of more resources to the military utility of space. Russia and China in particular are actively devoting additional resources towards space command assets and established specialist space units within their respective military establishments. ${ }^{5}$

In September 2002 the US Administration issued a landmark national security policy paper which emphasized the need for: 'Innovation within the armed forces [which] will rest on experimentation with new approaches to warfare, strengthening joint operations, exploiting U.S. intelligence advantages, and taking full advantage of science and technology. ${ }^{6}$ As an integral part of this policy, the Pentagon believed it was necessary to maintain technological supremacy so as to 'dominate the space dimension of military operations'. 7 The paper went on to note that this encompassed: 'the ability to defend the homeland, conduct information operations, ensure U.S. access to distant theaters, and protect critical U.S. infrastructure and assets in outer space. ${ }^{8}$

A measure of how far space weaponization and militarization has progressed is readily apparent in the establishment by the United States Air Force (USAF) of a space directorate to oversee the

\footnotetext{
${ }^{5}$ See e.g. William Scott, U.S. Adopts “Tactical” Space Control Policy 150 (13) AVIATION WEEK AND SPACE TECHNOLOGY 35 (1999).

${ }^{6}$ The White House, The National Security of the United States of America, September 2002, 30, available at <http://www.whitehouse.gov/nsc/nss.html> (last visited Jul. 20, 2006).

7 See Sa'id Mosteshar, Militarization of Outer Space: Legality and Implications for the Future of Space Law 47 PROCEEDINGS OF THE COLLOQUIUM ON THE LAW OF OUTER SPACE, footnotes 1 and 2 (2004).

${ }^{8}$ The White House National Security Document, supra note 6.
} 
operations of two activated space squadrons: the $76^{\text {th }}$ Space Control Squadron and the $527^{\text {th }}$ Space Aggressor Squadron. ${ }^{9}$ Thus, the world's major superpower now has in place a space force organized as a component of its Army, Navy, and Air Force, and falling under the overall control of United States Space Command (USSPACECOM). ${ }^{10}$

The determination of the United States (the US) to harness the military utility of outer space was cemented in 2002 when the United States withdrew from the Anti-Ballistic Missile (ABM) Treaty. ${ }^{11}$ The ABM treaty expressly prohibits development, testing and deployment of sea-based, air-based, space-based, and mobile land-based ABM systems. ${ }^{12}$ It is significant that the ABM Treaty was meant as an effective measure to limit anti-ballistic missile systems and thus act as a bulwark in curbing the race in strategic offensive arms. ${ }^{13}$ When the US withdrew from the Treaty, the key reason given was that it was outdated. ${ }^{14}$ However, it is clear that the withdrawal eliminated many of the legal obstacles shackling US endeavors to develop strategic weapon systems and, in particular, space-based devices critical to its National Missile Defense program.

The significance of space assets and US focus on military activities in space was amplified on 31 August 2006, when the US President—George W Bush—authorized a new national space policy

\footnotetext{
9 Thomas Ricks, Space Is Playing Field for Newest War Game: Air Force Exercise Shows Shift in Focus, WASHINGTON POST (Washington), Jan. 29 2001, 1

${ }^{10}$ See generally U.S. Air Force Space Command: Command News (2001) US SPACE COMMAND available at <http://www.spacecom.af.mil/hqafspc/news/default.htm> (last visited April 16, 2001).

${ }^{11}$ Colin Powell, Secretary of State, U.S. Department of State, Statement on the Achievement of the Final Reductions under the START Treaty, (2001), available at <http://www.state.gov/secretary/former/powell/remarks/2001/dec/6674.html> (last visited Aug. 12. 2006).

${ }^{12}$ Anti-Ballistic Missile Treaty, art. V, U.S.-U.S.S.R., opened for signature May 26, 1972, 23 U.S.T 3462, (entered into force Oct. 3, 1972) (emphasis added) [hereinafter ABM Treaty].

${ }_{13}^{13} I d$., Preamble.

14 John Diamond, Missile Pact on Brink: US Says Imminent Testing May Violate ABM Treaty, CHICAGO TRIBUNE (Chicago), Jul. 13, 2001 at 1.
} 
that centralises space as a pivotal aspect of its military operations. ${ }^{15}$ In an indication of the importance that the US accords to the military and security aspects of space technology, the policy emphasizes that its space capabilities are 'vital to its national interests' and that it will 'take those actions necessary to protect' these capabilities. Moreover, it goes on to assert that '[p]roposed arms control agreements and restrictions must not impair the rights of the [US] to conduct ... activities in space for U.S. national interests.' This approach inevitably elicits a similar and countervailing response from other major space-faring nations.

With China ascendant in the $21^{\text {st }}$ century, the space-technology rivalry (particularly its military utility) among the space powers is intensifying. It is to be remembered that, in 2000, China unveiled an ambitious 10-year space program. ${ }^{16}$ While one of the strongest immediate motivations for this program appears to be political prestige, China's space efforts are almost certainly geared to contribute to improved military space systems. ${ }^{17}$ With the US actively pursuing a National Missile Defense program, in 2003 a Chinese military official commented that China's army had already introduced the concept of 'space force strength', 18 in apparent reference to a similar US military concept. ${ }^{19}$ It is of significance that the Chinese space program has continually been under the command of senior officers of the People's Liberation Army. ${ }^{20}$

\footnotetext{
${ }^{15}$ U.S. National Space Policy (unclassified), http://www.ostp.gov/html/US\%20National\%20Space\%20Policy.pdf (last visited Sept. 10, 2007).

${ }_{16}$ Mark Wade, China, ENCYCLOPAEDIA ASTRONAUTICA, (2006), http://www.astronautix.com/articles/china.html (last visited May 17, 2006).

${ }^{17}$ Leonard David, Pentagon Report: China's Space Warfare Tactics Aimed at U.S. Supremacy, SPACE.COM, (2003), available at < http://www.space.com/news/china_dod_030801.html> (last visited Mar. 28, 2006).

${ }^{18}$ Id.

${ }^{19}$ In 1998 of the United States Space Command ('USSPACECOM') released details of its Long Range Plan outlining the US military vision for control of space and developing a capacity to project force from space. The first two mission statements of USSPACECOM's Long Range Plan are pointed: 'space support' and 'force enhancement' meaning the use of space assets to facilitate military operations of combat forces on land, sea, and air. The next two mission statements: 'space control' and 'force application' are more controversial as they suggest the weaponization of space, and are most closely related to combat in a future theatre of military space operations. Overall these four mission areas encapsulate 'space control': U.S. SPACE COMMAND, LONG RANGE PLAN: IMPLEMENTING
} 
Recent advances in space technologies have put the development of space weapons within the realm of possibility for several countries. As a USAF board report (New World Vistas: Air and Space Power For The 21st Century) states:

[i]n the next two decades, new technologies will allow the fielding of space-based weapons of devastating effectiveness to be used to deliver energy and mass as force projection in tactical and strategic conflict. These advances will enable lasers with reasonable mass and cost to affect very many kills. ${ }^{21}$

As the US pursues a policy that incorporates the placing of weapons in outer space, the other major space faring powers have not been idly sitting by. China's mid-term objectives for its ambitious space program include creating an integrated military Earth observation system, building Chinese-operated satellite broadcasting and telecommunications system $^{22}$ and fielding a constellation of space-based reconnaissance systems with real-time intelligence capabilities. ${ }^{23}$ The rapid advance of China's space capabilities was starkly illustrated on 11 January 2007, when the Chinese military launched a KT-1 rocket (an Anti-Satellite-ASAT-weapon) that successfully destroyed a redundant Chinese Feng Yun 1-C weather satellite. As details of the test emerged, Governments from around the world, including the US, Canada, United Kingdom and

USSPACECOM VISION FOR 2020 (1998). More significant was its sister document issued in 1999 by US Department of Defense ('DoD') which expanded upon, and reinforced themes raised by USSPACECOM's Long Range Plan. Among other space issues, the DoD policy states: 'Purposeful interference with US space systems will be viewed as an infringement on our sovereign rights. The US may take all appropriate self-defense measures, including, if directed by the National Command Authorities ('NCA'), the use of force, to respond to such an infringement on US rights': DEPARTMENT OF DEFENSE, DIRECTIVE 3100.10: SPACE POLICY (1999).

${ }^{20}$ Kremlin Voices Concern At US Conventional Missile Plans, DEFENSENEWS.COM (2006), available at <http://www.defensenews.com/story.php?F=1767408\&C=airwar> (last visited Aug. 12, 2006).

${ }^{21}$ A. T. Park, Incremental Steps For Achieving Space Security: The Need For A New Way Of Thinking To Enhance The Legal Regime For Space, 28 HOUSTON JOURNAL OF INTERNATIONAL LAW 871, 881(2006).

${ }^{22}$ China and Weapons of Mass Destruction: Implications for the United States: Conference sponsored by the US National Intelligence Council (NIC) and the Federal Research Division (FRD), Library of Congress (1999) Nuclear Threat Initiative available at <http://www.nti.org/e_research/official_docs/cia/11599CIA.pdf> (last visited Mar. 28 2006).

23 Mark Stokes, China's Strategic Modernization: Implications for the United States (1999) Strategic Studies Institute of the US War College available at http://www.strategicstudiesinstitute.army.mil/pdffiles/PUB74.pdf(last visited Mar. 28, 2006). 
Australia, all raised diplomatic concerns as to the nature of the test and its ramifications. ${ }^{24}$ The Chinese remained tight-lipped in the days following the test. Finally, twelve days later, and in the face of increasing anxiety amongst the international community, the Chinese Government acknowledged the test. China sought to allay concerns regarding its military nature by reaffirming that it was committed to the 'peaceful development of outer space'. ${ }^{25}$ However many were not convinced.

At the time, while some of the reaction of the international community centred on the military consequences of the test, others were concerned with another worrying aspect, the additional space debris caused by the destruction of the weather satellite. It is an unfortunate truism that armed military conflict will inevitably result in environmental damage, and this is equally the case in terms of space warfare. ${ }^{26}$ Although it is beyond the scope of this article to discuss the issue of space debris, the fact that China did not feel constrained by existing Space Law - in particular article IX of the Treaty on Principles Governing the Activities of States in the Exploration and Use of Outer Space, including the Moon and Other Celestial Bodies, (Outer

\footnotetext{
${ }^{24}$ In voicing its dismay at the test, a spokesperson for the United Kingdom Government was reported to have said:
}

We don't believe that this does contravene international law. What we are concerned about, however, is lack of consultation and we believe that this development of this technology and the manner in which this test was conducted is inconsistent with the spirit of China's statements to the $\mathrm{UN}$ and other bodies on the military use of space.

Ewen MacAskill, Michael White \& Brian Whitaker, Western Protests Flood in Over Chinese Satellite Killer, THE GUARDIAN, Jan. 20, 2007, at 18.

25 BBC News, China Confirms Satellite Downed, BBC NEWS ONLINE, (2007) available at <http://www.bbc.co.uk> (last visited Jan. 23, 2007).

${ }^{26}$ For a discussion of the environmental consequences of warfare and the possibilities for 'criminalizing'deliberate environmental destruction conducted as a strategy of armed conflict, see Steven Freeland, Crimes against the Environment - A Role for the International Criminal Court? in Alberto Costi and Yves-Louis Sage (eds) DROIT DE L'ENVIRONNEMENT DANS LE PACIFIQUE: PROBLÉMATIQUES ET PERSPECTIVES CROISÉES/ENVIRONMENTAL LAW IN THE PACIFIC: INTERNATIONAL AND COMPARATIVE PERSPECTIVES (New Zealand Association for Comparative Law/Association de Législation Comparée des Pays du Pacifique, RJP Hors Série no V, 2005) Chap. 12, 335-372. 
Space Treaty) ${ }^{27}$-or other principles of international law, highlights further the need to develop more rigorous international legal principles protecting the space environment.

In another development, just ten days after the Chinese satellite test, the Czech Government confirmed that it would be willing to host a large US military site for the Pentagon's missile shield system, with an auxiliary facility planned for Poland. ${ }^{28}$ The implications of the Czech Government statement, coming so soon after the Chinese test, added further to an increasingly troubling perspective. General Vladimir Popovkin, commander of the division of the Russian army in charge of space technology, stated that Moscow's 'analysis show[ed] that the location of the US base would be a clear threat to Russia. ${ }^{29}$ To underline the point, General Popovkin announced that Russia was bolstering its intercontinental missile arsenal, while at the same time threatening to withdraw from the 1987 Intermediate-Range Nuclear Forces (INF) Treaty ${ }^{30}$ with Washington, which limits short and medium range missiles in Europe. ${ }^{31}$

In a further escalation of the rhetoric, in February 2007, Russian President Vladimir Putin stunned senior diplomatic and political officials and academics at an international security conference with a vehement attack on US leadership in the world, ${ }^{32}$ claiming that the US had

\footnotetext{
${ }^{27}$ Treaty on Principles Governing the Activities of States in the Exploration and Use of Outer Space, including the Moon and Other Celestial Bodies, opened for signature 27 January 1967, 610 UNTS 205 (entered into force Oct. 10 1967).

${ }^{28}$ Ian Traynor, Czechs Give Go-Ahead For US 'Son of Star Wars', THE GUARDIAN, Jan. 22, 2007 at 14.

${ }^{29}$ Russian Ire at US Shield Not a Sign of Cold War Return, AGENCE FRANCE-PRESSE, Feb. 18 2007, available at 〈http://www.spacewar.com/reports/German_FM_Raps_US_Approach_To_Missile_Shield_Plan_999.html> (last visited June 8, 2007) .

${ }^{30}$ The Intermediate-Range Nuclear Forces (INF) Treaty was an agreement between the United States and the Soviet Union on Dec. 8, 1987. It came into force on June 1, 1987. The treaty eliminated nuclear and conventional groundlaunched ballistic and cruise missiles with ranges of 500 to 5,500 kilometers (300-3,400 miles).

${ }^{31}$ Russian Ire at US Shield supra note 29.

${ }^{32} I d$.
} 
'overstepped its borders in all spheres,' thus creating a dangerous 'uni-polar' world that had brought war, ruin and insecurity. ${ }^{33}$

The mounting tensions between Moscow and Washington came to a head on 29 May 2007, when Russia successfully tested a new intercontinental ballistic missile — the RS-24 — capable of penetrating American missile defenses. ${ }^{34}$ Russia's military noted that the missile had successfully hit its target 3,400 miles away in Kamchatka peninsula, on Russia's Pacific coast. ${ }^{35}$ Analysts noted that the new multi-warhead missile had the capability to destroy enemy systems and overcome any existing or future missile defense systems. ${ }^{36}$ In the aftermath of the announcement, Russia's hawkish first deputy prime minister, Sergei Ivanov noted with satisfaction that in terms of defense and security, Russia could look calmly to the future. His statement hinted at a new Cold War-style arms race. ${ }^{37}$

These stark reminders of the military aspects of space technology raise questions of international law and the current legal regime regulating the military uses of outer space. With the US determined to significantly increase its space militarization and weaponization program and SinoRussian cooperation, in the form of a formal 'strategic partnership', on the rise, it is imperative that the international community act sooner rather than having to react later to the ominous

\footnotetext{
${ }^{33} I d$.

${ }^{34}$ Luke Harding, Russian Missile test adds to Arms Rrace Fears, THE GUARDIAN, May 30, 2007 available at <http://www.guardian.co.uk/russia/article/0,,2091130,00.html> (last visited June 8, 2007).

${ }^{35}$ Alexander Pikayev, an arms control expert and senior analyst at the Moscow-based Institute for World Economy and International Relations, said the development of the missile had probably been inevitable after the Bush administration unilaterally withdrew from the Soviet-era anti-ballistic missile treaty in 2002, preventing the Start-II treaty from coming into force. The treaty banned missiles with multiple warheads. Harding, Russian Missile Test, id. . ${ }^{36}$ Harding, Russian Missile Test id.

${ }^{37}$ Russia's first deputy prime minister, Sergei Ivanov, said the country had tested both a new multiple-warhead intercontinental missile, the RS-24, and an improved version of its short-range Iskander missile. Harding, Russian Missile Test id.
} 
possibilities raised by the deployment of sophisticated space weapons systems. The United Nations is the obvious forum for this consultative process. It has maintained an active role in the passage of the leading multilateral treaties directly applying to the exploration and use of outer space and has an active Committee - the Committee on the Peaceful Uses of Outer Space ('COPUOS') — directed towards issues related to human activities in outer space.

\subsection{AVENUES FOR ANCHORING AND SECURING SPACE SECURITY}

\subsubsection{Re-orientating the Peace and Security Framework}

One of the most profound events at the start of the $21^{\text {st }}$ century in relation to international peace and security was the devastating terrorist attacks on 11 September $2001 .^{38}$ While these attacks marked what many have regarded as the 'maturation' of global terrorism, their ramifications were far wider. They pointed to the fact that drastic events beyond the contemplation of the drafters of the United Nations Charter would irrevocably change the international security environment. This was exemplified in the speech by President George W Bush in June 2002, when he asserted that:

[t]he gravest danger to freedom lies at the crossroads of radicalism and technology. When the spread of chemical and biological and nuclear weapons, along with ballistic missile technology-when that occurs, even weak States and small groups could attain a catastrophic power to strike great nations. ${ }^{39}$

\footnotetext{
${ }^{38}$ Four commercial aircraft were hijacked, two of them were flown into the twin towers of the World Trade Centre in New York City, causing both buildings to collapse, a third aircraft crashed into the Pentagon building in Arlington, Virginia, which houses the headquarters of the United States Department of Defense and the United States armed forces and the fourth aircraft, crashed near Somerset, Pennsylvania. Rensselaer Lee \& Raphael Perl, Terrorism, the Future, and US Foreign Policy (ISSUES BRIEF FOR CONGRESS) (2002) 1.

${ }^{39}$ George W Bush, Commencement Address (Speech delivered at the US Military Academy at West Point, 1 June 2002), quoted in The White House, The National Security Strategy of the United States of America, supra note 6.
} 
Though the speech was largely directed towards the growth of global terrorism, another theme was also present — the dangers of proliferation of technology. While President Bush focused on the dangers of advanced technology in the hands of terrorists, it is equally important that States themselves avoid developing space weaponization technology, which will otherwise lead the international community towards greater insecurity and an arms race. In this regard, several factors are relevant. First, States have proven to be just as irresponsible as non-State entities in the use of armaments. Secondly, new weapons technology has often only served to open new avenues for efficient killing, whether through the use of atomic devices, landmines or cluster bombs. Lastly, the nature of State hegemonic competition has always been dominated by a belief that economic and political power is underwritten by military might.

In the international arena, any threat to global security is a problem shared by all members of the United Nations, particularly when new technology points to development of deadly, devastating space weaponry. In this respect, it is important to recall that the security system established under the United Nations structure addresses both form and substance. Indeed, the United Nations Charter does not absolutely prohibit the use of force in all circumstances, but it does seek to regulate its use. As the use of military force becomes more sophisticated and complicated, the United Nations must contribute to both the practice and scope of the disarmament agenda with regard to space.

This represents a great opportunity for the United Nations and the process of constructive multilateral dialogue and regulation. What greater curative platform could there be than dealing with threats that have the potential of widespread deadly effects, but which have not yet 
materialized? To quote President John F Kennedy's observation during the Cuban Missile Crisis in 1962:

We no longer live in a world where only the actual firing of weapons represents a sufficient challenge to a nation's security to constitute maximum peril. ${ }^{40}$

It should be remembered that the justification for the Soviet nuclear build-up during the Cold War was that it was merely a reaction to a US-initiated arms race (and vice versa). Yet, there is no way that a convincing argument can be made in the present circumstances to the effect that maintaining international peace and stability is enhanced by ratcheting up an arms race in outer space, with its attendant correlative danger of the use of armed force. There is a need for the United Nations to carry out a re-appraisal of its regime on the use of force and re-interpret it within this new paradigm. The nature of modern space weaponry is such that there is great leeway for military confrontation to emanate from a misunderstanding, such as a malfunctioning laser that 'blinds' a third State's satellite, or an ASAT being hoisted into orbit which accidentally detonates, creating a deadly Van Allen Belt field that destroys a third State's military and/or civilian space assets. The Victim State may likely categorize this as a surprise 'Space Pearl Harbor' attack, particularly in an environment where space faring powers are increasingly anxious about the vulnerability of their space assets. ${ }^{41}$

\footnotetext{
${ }^{40}$ Charlotte Ku, When Can Nations Go To War? Politics and Change in the UN Security System, 24 MICHIGAN JOURNAL OF INTERNATIONAL LAW 1077, 1099 (2004).

${ }^{41}$ In 2001, a commission headed by former United States Secretary of Defense, Donald Rumsfeld, suggested that an 'attack on elements of U.S. space systems during a crisis or conflict should not be considered an improbable act': United States Department of Defense, Report of the Commission to Assess United States National Security Space Management and Organization, Jan. 11, 2001 available at <http://www.defenselink.mil/pubs/spaceintro.pdf >(last visited Mar. 12 2006) 8. The Report went on to (in)famously warn of the possibility of a 'Space Pearl Harbor' - a surprise attack on the space assets of the United States.
} 
In certain aspects, the existence of the United Nations as a quasi-universal international institution has fundamentally changed the character of the international system and the postWorld War II international security system. This is based on the reality that, despite a number of (sometimes significant) failings, the United Nations Charter has shown itself capable of adapting to a variety of new tasks, although this process remains incomplete. While the United Nations Charter system as a means to restrain the use of force has developed more fully than its ability to authorize and to enable States to use force against a member State, Article 1 remains pivotal to the mandate of the United Nations. That provision articulates a central purpose of the United Nations - 'to take effective collective measures for the prevention and removal of threats to the peace, and for the suppression of acts of aggression.'

Given that the world had just emerged from a catastrophic war, the United Nations was founded to concentrate first and foremost on the peaceful settlement of international disputes and to rely on the military instrument of policy only as an extreme last resort. ${ }^{42}$ The Security Council is required to fulfill a central constitutive principle of the United Nations, stated in the Charter's preamble: 'to save succeeding generations from the scourge of war.' The undercurrent is a recognition that the United Nations Charter, although drafted before the advent of intercontinental ballistic missiles, weapons of mass destruction (WMDs) and space weapons, can accommodate a mandate to address the weaponization of space, but only if the United Nations seizes the chance before rather than after space powers actively deploy weapons and weapons systems in outer space. Ideally this would require a move from the prevailing United Nations

\footnotetext{
${ }^{42}$ Jules Lobel \& Michael Ratner, Bypassing The Security Council: Ambiguous Authorizations To Use Force, CeaseFires And The Iraqi Inspection Regime, 93 AMERICAN JOURNAL OF INTERNATIONAL LAW 124 (1999).
} 
strategy of issuing regular calls for a '[p]revention of an arms race in outer space' 43 to the establishment of rigorously enforced moratorium on the deployment of weapons in outer space, which might then offer a window of opportunity to negotiate a total ban of weapons in outer space. Naturally, this would require a significant shift in political will among the major spacefaring nations, which although a difficult task, should be encouraged through negotiation and broader political pressure.

\subsubsection{Coercive Arms Control: 'Coming Down to Earth'}

On 7 June 1981, the Israeli air force bombed the Iraqi nuclear complex at Tuwaitha. ${ }^{44}$ The attack was strongly condemned by the Security Council as a 'clear violation of the Charter of the United Nations and the norms of international conduct. ${ }^{45}$ Nearly ten years after voting to condemn the Israeli raid, the United States struck at the same target during the first Gulf War. ${ }^{46}$ Unlike the Israeli raid, the American action was not denounced by the Security Council. In rallying national and international support for its stand against Iraq, President George Bush Sr. stressed not only the economic consequences of Iraq's control over Kuwait's oil, but Iraq's unconventional weapons capability, which it identified as the pre-eminent danger. ${ }^{47}$

\footnotetext{
${ }^{43}$ There have been a series of General Assembly resolutions to this effect, beginning with Resolution 36/97C, 9 December 1981 with the most recent being Resolution 61/58 on 6 December 2006. The political dimensions of this issue in the early 1980s were indicated by a split, along ideological grounds, on the main thrust of these resolutions: see Nandasiri Jasentuliyana, INTERNATIONAL SPACE LAW AND THE UNITED NATIONS, 82 (1999). Despite the frequency of such resolutions, the militarization and weaponization policies of the major space-faring nations have continued largely unabated.

${ }^{44}$ David K Shipler, Israeli Jets Destroy Iraqi Atomic Reactor, NEW YORK TIMES (New York), June 9 1981, A1.

${ }^{45}$ On the Israeli Military Attack on Iraqi Nuclear Facilities, SC Res 487, UN SCOR, $36^{\text {th }}$ Sess, $2288^{\text {th }} \mathrm{mtg}$, UN Doc S/RES/487 (1981).

${ }^{46}$ Rick Atkinson \& Ann Devroy, U.S. Claims Iraqi Nuclear Reactors Hit Hard, WASHINGTON POST (Washington), Jan 12, 1991 at A1.

${ }^{47}$ See James Baker, Why America Is in the Gulf 1 DEPARTMENT OF STATE DISPATCH 235 (1990); McGeorge Bundy, Nuclear Weapons and the Gulf 70(4) FOREIGN AFFAIRS 83, 89 (1991).
} 
Indeed, the Security Council subsequently endorsed the strike and, as part of its terms to end the war, ordered Iraq to destroy all manufacturing capabilities for the production of nuclear, chemical, and biological weapons, as well as those for ballistic missiles. ${ }^{48}$ While Iraq's nuclear and biological weapon programs may have violated its treaty obligations, ${ }^{49}$ its possession of chemical weapons and ballistic missiles was not prohibited by international law. At the time that Security Council Resolution $687^{50}$ was adopted, only the use of chemical weapons was prohibited by international law. ${ }^{51}$ The Security Council's blanket demand that Iraq be prohibited from manufacturing weapons of mass destruction, regardless of Iraq's actual international legal obligations, supports an argument that a coercive arms control agenda can fit within the mandate of the United Nations. In the aftermath of the first Gulf War, scholars and diplomats considered whether the Security Council, by omission and commission, had ushered in a new world order, 'an order where "coercive arms control" is both a legal and legitimate instrument of statecraft'. ${ }^{2}$

These reflections support the argument of the potential of the expansive language of Article 1 of the United Nations Charter to implicitly serve as legal authority for coercive arms control. ${ }^{53}$ In

\footnotetext{
${ }^{48}$ On Restoration of the Sovereignty, Independence and Territorial Integrity of Kuwait, SC Res 687, UN SCOR, $46^{\text {th }}$ sess, $2981^{\text {st }} \mathrm{mtg}$, UN Doc S/RES/678 (1991).

${ }^{49}$ Iraq is party to the Treaty on the Non-Proliferation of Nuclear Weapons, opened for signature July 1, 1968, 729 UNTS 161 (entered into force Mar. 5, 1970), and to the Convention on the Prohibition of the Development, Production and Stockpiling of Bacteriological (Biological) and Toxin Weapons and on Their Destruction, opened for signature 10 April 1972, 1015 UNTS 163 (entered into force Mar. 26, 1975).

${ }_{50}^{50}$ S/RES/687 (1991), 2981st mtg, April 81991.

${ }^{51}$ Convention on the Prohibition of the Development, Production, Stockpiling and Use of Chemical Weapons and on their Destruction, opened for signature Jan. 13, 1993, 32 ILM 800 (entered into force April 29, 1997). In regard to ballistic missiles, the first relevant international law was the Missile Technology Control Regime ('1987 MTCR'), which merely seeks to control the export of long-range (more than 300 kilometers) ballistic missile equipment and technology: see Agreement on Guidelines for the Transfer of Equipment and Technology Related to Missile: Exchange of Letters Between Canada, France, Federal Republic of Germany, Italy, Japan, United Kingdom, and the United States (April 7, 1987) 26 ILM 599. The 1987 MTCR was replaced by a later (1993) version, which extended the scope of the controls beyond only nuclear delivery systems to delivery systems capable of carrying all types of weapons of mass destruction.

${ }^{52}$ Roger K Smith, The Legality of Coercive Arms Control, 19 YALE JOURNAL OF INTERNATIONAL LAW 455, 457 (1994).

${ }^{53} \mathrm{Id}$. at 459 .
} 
tandem with this, Chapter VII of the Charter specifies how the United Nations is to exercise this broad authority by providing that:

[t]he Security Council shall determine the existence of any threat to the peace, breach of the peace, or act of aggression and shall make recommendations, or decide what measures shall be taken in accordance with Articles 41 and 42, to maintain or restore international peace and security. ${ }^{54}$

That Article 39 of the United Nations Charter grants wide discretionary power to the Security Council is supported by the fact that the drafters of the Charter did not offer precise definitions as to what constitutes a 'threat to the peace,' a 'breach of the peace,' or an 'act of aggression. ${ }^{55}$ Although the General Assembly eventually reached a rather limited definition of aggression, the Security Council is not bound by it. ${ }^{56}$ Given the history of the Security Council, the reality is that the scope of these terms is fluid and could well embrace the emerging space arms race by allowing the Security Council an avenue to classify certain activities in space as 'acts of aggression'. This would enable the regulation of the deployment by space faring powers of devices that are obviously geared to be offensive.

This position is further supported by the unanimous adoption by the Security Council of a resolution imposing limited sanctions on North Korea for its missile tests and demanding that the reclusive communist nation suspend its ballistic missile program after its 5 July 2006 testing of several mid-range missiles and a long-range missile. ${ }^{57}$ The resolution not only condemns North Korea's multiple missile launches but demands that North Korea 'suspend all activities related to

\footnotetext{
${ }^{54}$ Charter of the United Nations art 39.

${ }^{55}$ Leland M Goodrich et al, CHARTER OF THE UNITED NATIONS: COMMENTARY AND DOCUMENTS 295 $\left(3^{\text {rd }}\right.$ revised ed, 1969).

${ }_{57}^{56}$ Definition of Aggression, GA Res 3314, UN GAOR, $29^{\text {th }}$ sess, $2319^{\text {th }}$ plen mtg, UN Doc A/RES/3314 (1974).

${ }^{57}$ Letter dated 4 July 2006 from the Permanent Representative of Japan to the United Nations addressed to the President of the Security Council (S/2006/481), SC Res 1965, UN SCOR, $61^{\text {st }}$ sess, $5490^{\text {th }} \mathrm{mtg}$, UN Doc S/RES/1695 (2006).
} 
its ballistic missile program; even though the tests in and of themselves were not illegal, nonetheless they represented a threat to international peace and security. This move by the Security Council sends a message that the world powers can work together and that the United Nations can effectively send a united message.

However, the Security Council must desist from double standards. In terms of destructive weaponry there is no such standard as 'responsible' and 'irresponsible' States. The only issue is the likelihood of deployment. To illustrate this concern, only three days after the North Korea test India launched its own long-range missile test which was not denounced. Regulation of the deployment of weapons in space should be consistent, unless the United Nations wishes to again become enmeshed in a situation where some States are able to officially enter into the 'Nuclear Club', and then close doors and adopt a paternalistic approach to others. This position does more damage in terms of nuclear proliferation than the whole policy towards so-called rogue nations.

Reinforcing this sentiment is the ongoing dilemma faced by the international community over Iran's nuclear program. Iran argues that it has a legal right to enrich uranium for peaceful purposes under the Nuclear Non-Proliferation Treaty ('NNPT'), ${ }^{58}$ a right which in 2005 the US and the European Union ('EU') began to assert had been forfeited by a 'clandestine' nuclear programme. While it is beyond the scope of this article to deal with this contentious issue in detail, it should be noted in passing that Iran has frequently compared its treatment to other nations that have developed an indigenous nuclear weapons capability: Israel, India and Pakistan. Unlike these three States, Iran is a State Party to the NNPT; it is precisely on this basis that Iran

\footnotetext{
${ }^{58}$ Treaty on the Non-Proliferation of Nuclear Weapons opened for signature July 1, 1968, 729 UNTS 161 (entered into force Mar. 5 1970).
} 
argues that it has a right to develop, research, and engage in the production and use of nuclear energy for peaceful purposes.

Arms control policy and strategy, perceived as a program and framework in which the international community shares common objectives can be achieved on a basis of shared expectation and agreements, which serve the international community by providing greater strength and public security. In this vein, it may be the time to dust off some of the ideas encompassed by previous initiatives. For example, in 1957, Western States, including the US proposed the creation of an inspection system which would ensure the use of outer space exclusively for peaceful and scientific purposes. ${ }^{59}$ About three decades later in 1985, as the realization dawned that the US had leapt significantly ahead of it in the development of space weapon technology, the former Soviet Union proposed the creation of a 'World Space Organization,' which would ensure 'international cooperation in the peaceful uses of outer space in the context of its non-militarization. ${ }^{60}$ These proposals ought not to be viewed as simplistic pipe dreams, but rather as the basis for serious propositions that may well afford the international community the opportunity to engage in serious deliberations to address and contain the matter of space weaponization.

\subsubsection{Resolving the 'Peaceful Purposes' Conundrum: Banning Space Weaponry}

In the process of banning the placement of WMDs in orbit and the establishing of military bases in space, the Outer Space Treaty codified the term 'peaceful use of outer space.' However, no

\footnotetext{
${ }^{59}$ Bruce A Hurwitz, THE LEGALITY OF SPACE MILITARIZATION 174 (1986).

${ }^{60}$ Id. at 176 (citing Radio Moscow, Aug. 17, 1985 and Oct. 2, 1985).
} 
consensus has been reached as to a universal definition of the term 'peaceful., ${ }^{61}$ To many, the term 'peaceful' has become synonymous with the term 'non-aggressive' rather than 'nonmilitary', thereby implying that 'all military uses were and are allowed and lawful as long as they remain 'non-aggressive'.'

Indeed, one could even go so far as to suggest that the 'non-military vs. non-aggressive' debate is a redundant argument, even though it represents an extremely important issue of interpretation of the Outer Space Treaty. The discussion should now centre on issues involving the weaponization of space. In one sense, this assumes that the militarization of space is a given, even though this flies in the face of the Outer Space Treaty. Yet, it would be naive to ignore the realities - what must be done is instead to understand what legal principles currently apply to any military activities in space and what more needs to be done to provide, at least from a regulatory perspective, an appropriate framework to protect humankind from what could otherwise be unimaginable scenarios.

The Outer Space Treaty amounts to the 'Constitution' of outer space. It was the first treaty to not only set rules governing access to space, but more pertinently, it addresses the issue of space weaponization, at least to a certain degree. The fundamental premises of the Outer Space Treaty are that space is not open to national appropriation but should be reserved for the pursuit of the common interest of mankind and for 'peaceful purposes.'

Various principles in the treaty have been expanded in subsequent treaties. ${ }^{62}$ However, the Outer Space Treaty has largely been untested, and although binding under traditional rules of

\footnotetext{
61 Sarah Estabrooks, Opposing Weapons in Space (2002) Ploughshares Monitor available at <http:// www.ploughshares.ca/libraries/monitor/mons02a.html> (last visited Aug. 12 2006).

${ }^{62}$ Agreement Governing the Activities of States on the Moon and Other Celestial Bodies (Moon Agreement), opened for signature Dec. 18, 1979, 1363 UNTS 21 (entered into force 11 July 1984); Agreement on the Rescue of Astronauts, the Return of Astronauts and the Return of Objects Launched into Outer Space, opened for signature April 22, 1968, 672 UNTS 119 (entered into force Dec. 3, 1968); Convention on International Liability for Damage Caused by Space Objects, opened for signature 29 March 1972, 961 UNTS 187 (entered into force Sep 1., 1972)
} 
international law, its principles are seen by some States to a degree as 'aspirational., ${ }^{63}$ Consequently space powers have determined that military support activities such as observation, surveillance, communications, and the detection of nuclear explosions on Earth are 'passive', thus falling under the umbrella of 'peaceful purposes'. ${ }^{64}$

\section{As Andrew T Park notes:}

While all hope for preserving space for peaceful purposes is not lost, [there is a need to] narrow the definition of peaceful purposes if progress is to be achieved. The era of space as a truly peaceful sanctuary may be gone, but it may not be too late to regulate space activities in an effort to mitigate the potential of space weaponization. ${ }^{65}$

The United Nations Conferences on Disarmament, the General Assembly, COPUOS, and the international scientific community has proclaimed and repeatedly affirmed that outer space shall be used for peaceful purposes, not for military advantage. ${ }^{66}$ Even if one were to continue to accept the use of the non-military/non-aggressive dichotomy, 'no case can be made for a spacebased weapon systems consistent with this norm. ${ }^{67}$ This is in light of the explicit pacta sunt servanda provisions of the Vienna Convention on the Law of Treaties. ${ }^{68}$

This imperative was articulated during special proceedings of the American Society of International Law in 1985 when Professor Martin Feinrider noted that the principle of pacta sunt

\footnotetext{
${ }^{63}$ Park, supra note $21,877$.

${ }^{64}$ See Abram Chayes et al, Space Weapons: The Legal Context, in Franklin A Long et al (eds), WEAPONS IN SPACE 193, 196-7 (1986).

${ }^{65}$ Park, supra note $21,884$.

${ }^{66}$ Colleen Sullivan, The Prevention of an Arms Race in Outer Space: An Emerging Principle of International Law' 4 TEMPLE INTERNATIONAL AND COMPARATIVE LAW JOURNAL 211 (1990).

${ }^{67}$ Nitza Milagros Escalera, Arms Control and U.S. Policy: 'Star Wars,' Mad Max And Pershing IIS 79 AMERICAN SOCIETY OF INTERNATIONAL LAW PROCEEDINGS 233, 235 (1985).

${ }^{68}$ Vienna Convention on the Law of Treaties, opened for signature May 23, 19691155 UNTS 331, (entered into force Jan. 27, 1980)
} 
servanda (the principle of good faith) means that 'international law [is] binding on all nations, including both superpowers'. Professor Feinreider cautioned that it is not appropriate to 'rely on strained readings of text and disingenuous presentations of fact to erode legal obligations and thus rationalize avoidance of constraints on state behavior' ${ }^{69}$ This is particularly relevant to one of the central provisions of the Outer Space Treaty - Article III — which provides that States shall carry out activities in space in accordance with international law, including the United Nations Charter, in the interest of maintaining international peace and security. In essence this should preclude the utilization of space as a medium of warfare. The only possible exception would be a defensive system, but this is a slippery slope, considering the dual-purpose nature of space technology. In any case no nation should feel the need for a defensive system in space when no space weapons are deployed. The best paradigm would be a blanket proscription of any deployment of weapons in space.

The position is no doubt complicated by the fact that Article 51 of the United Nations Charterwhich confirms the 'inherent right' of self-defense 'if an armed attack occurs ${ }^{70}$ — is relevant to the legal regulatory regime. However, under the principles of public international law, this right of self-defense remains subject to express legal limitations.. In its Advisory Opinion in the Legality of the Threat or Use of Nuclear Weapons, the International Court of Justice observed: ' $[\mathrm{t}]$ he submission of the exercise of the right of self-defense to the conditions of necessity and proportionality is a rule of customary international law. ${ }^{, 71}$. The use of space weapons, with the

\footnotetext{
${ }^{69}$ Id. 234.

${ }^{70}$ Article 51 of the Charter provides inter alia: 'Nothing in the present Charter shall impair the inherent right of individual or collective self-defense if an armed attack occurs ...'

${ }^{71}$ [1996] 1 ICJ Rep. 245, para. 41. See also The Caroline Case 29 B.F.S.P. 1137-1138; 30 B.F.S.P. 195-196, which referred as well to a requirement of immediacy, although this was not mentioned in the decision of the International Court of Justice in Oil Platforms (Merits) (Iran v. United States) [2003] ICJ Rep. Judgment of Nov. 6, 2003.
} 
capability to render massive destruction and injury (either directly or indirectly), may well violate the principles of proportionality.

The desirability of a blanket proscription of weapons deployment in space is supported by several illustrations. One of the major space-faring powers, the Soviet Union (now Russia) has argued in the past and maintains the position that, based upon contemporary international law, it is important that outer space be excluded from the sphere of the arms race and that all channels for militarization and weaponization of outer space should be blocked. It is significant that the Soviet Union proposed successive 'radical' solutions for the prevention of the militarization and weaponization of space, notwithstanding that for a while it had the capacity and capability to transform itself into a peerless space power along with the US. As early as 1981 the Soviet Union submitted to the United Nations Committee on Disarmament a Draft Treaty on the Stationing of Weapons of any Kind in Outer Space., ${ }^{72}$ which sought to ban deployment of all types of weapons in outer space and to provide for the use of national technical monitoring facilities.

Two years later, the Soviet Union made specific proposals on banning and eliminating space attack weapons, as well as any land, air or sea-based systems designed to destroy objects in outer space and proposed to the General Assembly, the conclusion of a treaty on the prohibition of the use of force in outer space and from space against the Earth. The main elements of the draft treaty were:

\footnotetext{
72 See General and Complete Disarmament, GA Res 36/97, UN GAOR, 36 ${ }^{\text {th }}$ sess, $91^{\text {st }}$ plen mtg, UN Doc A/RES/36/97 (1981).
} 
(1) The prohibition of the testing or deployment by placing in orbit around the Earth or stationing on celestial bodies or in any other manner of any space-based weapons for destruction of objects on the Earth, in the atmosphere or in outer space.

(2) The prohibition of the use of space objects in orbit around the Earth, on celestial bodies or stationed in outer space in any other manner as means to destroy any targets on the Earth, in the atmosphere or in outer space.

(3) The obligation of states not to destroy, damage, or disturb the normal functioning or change the flight trajectory of space objects of other states.

(4) The prohibition of the testing or creation of new anti-satellite systems and the destruction of such systems that may already exist.

(5) The prohibition of the testing or use of manned space craft for military, including anti-satellite, purposes.

(6) The provision for a broad range of measures to verify compliance with the obligations envisaged by the treaty. ${ }^{73}$

The Soviets proposed that the exclusion of outer space from the sphere of the arms race is an international obligation, and that the prevention of militarization would provide an opportunity for the peaceful use of space as a means to solve the acute economic, social and cultural development problems facing mankind. The General Assembly subsequently took this on board, noting its grave concern regarding the extension of an arms race into outer space and requesting the conclusion of a treaty to safeguard international peace and security. ${ }^{74}$

Interestingly, in 2003, China publicly declared 'that space should not be militarized and that space technologies should be used for peaceful purposes' ${ }^{75}$ This is even more poignant when one considers that this was the same year that China joined the 'Space Club' elite after becoming only the third nation in the history of humankind to successfully launch a manned space flight.

On the one hand, some might seek to characterize the Soviet (Russian) proposals and the Chinese statements as some semblance of 'momentum' towards the prohibition and elimination of attack space weapons and all other systems designed to destroy objects in space. Yet, clearly the

${ }^{73}$ Quoted in Escalera, Arms Control and U.S. Policy, supra note 67, at 245.

${ }^{74}$ Id.

75 William S Murray III and Robert Antonellis, China's Space Program: The Dragon Eyes the Moon (and Us) 47 ORBIS 645, 649 (2003). 
situation is not straightforward, with the current US National Space Policy and its missile defense shield proposals, together with the vitriolic responses elicited from both Russia and China, as significantly dampening any current hopes for a space weapons 'détente'. ${ }^{76}$

In sum the future of space security will depend on how effectively all States strive for the 'deweaponization' of outer space and pressure the major space faring nations, and how those nations are able to set aside their differences. If they cannot, outer space will become even more susceptible to the exploitation of weapons technology. The ideal solution undoubtedly involves an extremely difficult exercise in international diplomatic negotiation, and the authors have no magic panacea as to how this might best be achieved in the short term. However, over time it is to be hoped that all stakeholders will come to realize that the alternate scenarios are far more frightening to contemplate.

\subsubsection{Strengthening the Principles Underlying the Outer Space Treaty}

The sentiments underlying the United Nations Charter were strengthened by the restrictions imposed in relation to nuclear weapons and weapons of mass destruction by Article IV of the Outer Space Treaty, although this provision in and of itself does not represent a complete restriction on the placement of weapons in outer space. ${ }^{77}$ There have, from time to time, been

\footnotetext{
${ }^{76}$ See, for example, Putin warns Europe in Missile Row, BBC WORLD NEWS, June 32007 available at 〈http:www.bbc.co.uk> (last visited June 3, 2007).

${ }^{77}$ See, for example, Gyula Gál, "Threat or Use of Force"-Observations to Article 2 of the U.N. Charter and Article III of the Outer Space Treaty' 17:1 JOURNAL OF SPACE LAW 54, 57 (1989).
} 
proposals to amend Article IV in order to enhance these restrictions, but none of these has (yet) been accepted. $^{78}$

Some commentators argue that the determination of a peaceful use of space depends on the purpose of the activity. ${ }^{79}$ The position taken is that 'purpose' is 'an intended or desired result; end, aim; goal. ${ }^{80}$ Extrapolating these positions would mean that arguments against the militarization and weaponization of outer space per se are rendered redundant, since the assertion by space faring nations is that their programs are geared towards advancing national self-defense — a 'peaceful purpose' and in any event one contemplated within the United Nations Charter.

Major Robert Ramey notes that the international space law regime discloses that, at a minimum, the following military activities in outer space are not comprehensively prohibited:

1. The use of military personnel;

2. The use of space-based remote sensors in support of combat or other military purposes;

3. The use of space-based communication, navigation, and meteorological systems for combat or other military purposes;

4. The deployment and non-aggressive use of conventional space weapons; and

5. The transiting of nuclear and other weapons of mass destruction in non-orbital trajectories. ${ }^{81}$

Despite these potential 'loopholes', however, the reality is that the international law principles regulating the use and exploration of outer space require that 'outer space' be used for 'peaceful purposes'. The concept is an accepted axiom of customary international law and continues to be

\footnotetext{
${ }^{78}$ See, for example, Vladimir Bogomolov, Prevention of an Arms Race in Outer Space: The Deliberations in the Conference on Disarmament in 1993 21:2 JOURNAL OF SPACE LAW 141, 141 (1993) where the author refers to a failed Venezuelan proposal to amend Article IV.

${ }^{79}$ Robert Bridge, International Law and Military Activities in Outer Space 13 AKRON LAW REVIEW 649, 658 (1979).

${ }^{80}$ Richard Morgan, Military Use of Commercial Communication Satellites: A New Look at the Outer Space Treaty and "Peaceful Purposes", 60 JOURNAL OF AIR LAW AND COMMERCE 237, 305 (1994).

${ }^{81}$ Major R. Ramey, Armed Conflict on the Final Frontier: The Law of War in Space, 48 AIR FORCE LAW REVIEW 1, 157 (2000).
} 
recognized in the majority of space-related international agreements and United Nations declarations or resolutions. The term 'peaceful' can also be found in virtually all United Nations documents devoted to outer space matters.

The Conference on Disarmament observed in 1986 that:

Outer space should be used exclusively for peaceful purposes for the benefit of ... mankind. No country should develop, test or deploy space weapons in any form. An international agreement on the complete prohibition of space weapons should be concluded through negotiations as soon as possible. ${ }^{82}$

The 'peaceful purposes' principle establishes a norm in support of the maintenance of outer space for such purposes. This norm has been sustained for nearly forty years and, in the process, has ensured that the realm of space would not be used as a battleground for international actors to settle their disputes. In order for this standard to carry weight with regard to space weaponization, a normative legal regime for the future of space needs to be elaborated. Although not without its shortcomings, the Outer Space Treaty has, for the most part, withstood the test of time and the expansion of many (though not all) of the new modes of utilizing outer space. It is suggested, therefore, that for this precise reason, an effort to strengthen the principles that is reflects must be pursued.

John Rhinelander and Philip Coyle advocate for a unanimously endorsed amendment to the Outer Space Treaty to prohibit State deployment of military assets in space that may fall short of the 'peaceful purposes' paradigm. Such a position is to be commended since it would generate

\footnotetext{
${ }^{82}$ Conference on Disarmament, Final Record of the $350^{\text {th }}$ Plenary Meeting, UN Doc. CD/PV.350 (1986).
} 
significant and valuable momentum. ${ }^{83}$ However, this strategy would first require that the States Parties to the Outer Space Treaty convene a meeting. The most substantial barrier to an amendment is likely to be the reluctance of States to accept new limitations upon their sovereign autonomy to use force in space, particularly in an era when they increasingly believe that control of outer space is of vital concern to their national interests. Discussions at the regular COPUOS Legal Subcommittee Meetings suggest that any proposal to amend the space treaties would not be accepted under the consensus-based decision making processes of that body.

Given the shortcomings of the COPUOS consensus approach in this regard, consideration should be given to establishing an alternate forum for discussion, starting with either a variant of a United Nations subcommittee, or perhaps convocation of major space-faring nations, but also involving the participation of interested non-space-faring nations and legal experts. The main focus of the forum would be to address in detail the prospect of promoting 'no first deployment pledges', encouraging transparency and establishing other confidence building measures. The important goal would be to ensure the presence and good-faith participation of the major spacefaring nations. The approach should be to negotiate rules to ensure that commercial, security, and scientific interests in space are secured. This would require the establishment of a normative approach that balances the interests of all those States involved in outer space activities but, at the same time:

emphasizes international cooperation among all parties with an interest in space' with the ultimate goal being embodied in a treaty that would be designed to prevent the predominance of any single power in space. $^{84}$

\footnotetext{
${ }^{83}$ See Philip E Coyle and John B Rhinelander, Drawing the Line: the Path to Controlling Weapons in Space, 66 DISARMAMENT DIPLOMACY 27 (2002).

${ }^{84}$ Park, supra note 21, 891.
} 
Recent developments and Governmental policies emanating from the major space-faring nations do not give cause for overwhelming optimism that such an approach can be successfully agreed. One possible conclusion might be that any attempt to limit (let alone prohibit) space weaponization appears a utopian dream rather than a real possibility. Yet, there are other possibilities, stemming from the humanity and cooperative principles of space law and the realities of what fate may await us if space weaponization is, indeed, left unbridled. A combination of cool heads and the establishment of initiatives directed towards cooperation rather than confrontation are urgently required to diffuse these worrying developments.

The use of satellites for communication, navigation, space flight, meteorology, remote sensing, disaster reduction and other fields of science and technology is indispensable for peaceful scientific and exploration endeavours. While achieving notable progress in the peaceful uses of outer space, humanity is nonetheless faced with seemingly ever-expanding military requirements including increased levels of weaponization spurred by active and continuing research into and testing of space weapons. International security and stability requires that peaceful capabilities be sustained and advanced within an internationalized context. Currently, various aspects of space asset management are discussed in widely different fora with little crossover in participation. To guard against the vagaries of changing fortunes and shifting international alignments, the United Nations will need to consider ways of increasing the scope of its jurisdiction over domestic space weaponization activities, based on its mandate for the maintenance of international peace and security.

Given that space security involves commercial, military, scientific and political aspects, it might be worthwhile considering how to ensure that efforts directed towards the promotion of space 
security in the different realms are coordinated. While the answer may simply be to reinvigorate COPUOS, the international community should consider the creation of a new and voluntary annual gathering of all space stakeholders.

\subsubsection{Reflections: Cross Roads-Leveraging Silver Bullets through the Green Bullet}

As discussed above, Space Law regime has an interpretational flexibility which exposes serious internal contradictions. The 'peaceful purposes' centre-piece of Space Law does not rule out the military use of outer space or of commercial communications satellites. The Space Law regime yields little information on space warfare. Although major powers have pursued space militarization and weaponization for decades, this has not been done to ensure a fair fight between two opponents. Instead, we have witnessed a race to space supremacy.

There is little doubt that the paradigms outlined above are compelling and feasible. However, as the authors acknowledge above, the realpolitik associated with 'nation security interests' are complex at best and untidy at worst. Perhaps a trump card would be to use international environmental law as a lever.

The international community has generally approached the space weapons issue solely in terms of arms control. COPUOS ${ }^{85}$ has recognized that weaponizing space undermines both non-

\footnotetext{
85 COPUOS is designed essentially to facilitate governmental exchange of space information and promote international cooperation in the peaceful use of space. See UN Committee on the Peaceful Uses of Outer Space: History and Overview of Activities, available at <http://0www.unoosa.org.library.newcastle.edu.au:80/oosa/COPUOS/cop_overview.html> (last visited on Nov. 19, 2006).
} 
proliferation efforts and the notion of maintaining outer space for peaceful purposes ${ }^{86}$ and has therefore opened dialogue on space weapons. However, the US (often aided and abetted by other powers) has attempted to ensure that disarmament issues remain only within the mandate of the UN Conference on Disarmament ('CD'), ${ }^{87}$ thus severely limiting COPUOS's scope of enquiry. ${ }^{88}$ In light of steadfast US hostility and a general unwillingness to agree to a weapons-free space environment, perhaps the matter can be articulated with less acrimony and a larger measure of understanding through the lens of environmental protection, which offers a less contentious platform for curtailing space weaponization. As Lori Scheetz notes, by

[e]mploying an international environmental framework, the international community can address issues outside of traditional national security interests, such as the obligations of the present generation to prevent destruction of the space commons resulting from the development or use of space weapons. ${ }^{89}$

\subsubsection{The 'Green' Panacea-International Environmental Law}

Space is a particularly delicate and fragile environment, with little capability to self-regulate and effectively rid itself of debris. ${ }^{90}$ Its ability to 'repair' itself is uncertain. ${ }^{91}$ Only the Earth's

\footnotetext{
${ }^{86}$ UN Committee on the Peaceful Uses of Outer Space [COPUOS], Report of the Committee on the Peaceful Uses of Outer Space, UN Doc. A/60/20(SUPP) (June 13, 2005) para 25.

87 Disarmament, UN Office at Geneva, available at <http:// www.unog.ch/80256EE600585943/(httpHomepages)/6A03113D1857348E80256F04006755F6? OpenDocument> (last visited on June 5, 2007).

${ }^{88} I d$.

89 L. Scheetz, Infusing Environmental Ethics into the Space Weapons Dialogue, 19 GEORGETOWN INTERNATIONAL ENVIRONMENTAL LAW REVIEW 57, 59 (2006).

${ }^{90}$ It extremely difficult to determine precisely what debris is and when something gains that status. However, for a working definition the authors adopt Professor Marietta Benkö's observation that: 'Space debris are non-functional objects in outer space without regard whether they are still intact or broken up to any size like deactivated satellites or parts thereof.' M. Benkö, The Problem of Space Debris: A Valid Case Against the Use of Agressive Military systems in Outer Space?, in M. Benkö \& K. U. Scrogl (Eds.), CURRENT PROBLEMS AND PERSPECTIVES FOR FUTURE REGULATION, 155 (2005). This seems to synthesize concisely the basic elements of most commentators attempts who note that generally, space debris falls into four identifiable categories, which include inactive payloads, operational debris, fragmentation debris, and microparticulate matter. H. A. Baker, Space Debris: Legal and Policy Implications, at 3 (1989).
} 
atmosphere can remove satellites from orbit. ${ }^{92}$ But this is only of limited utility as it applies only to Low Earth Orbit ('LEO'). With objects in Geo-Synchronous Orbit ('GEO') and SunSynchronous Orbit ('SSO') there is less air, hence reducing the ability for gravitational drag and potential ejection of debris. ${ }^{93}$ Disturbingly, once debris settles into orbit at more than 1,500 kilometers above Earth's surface, it remains there indefinitely, continuously orbiting Earth at up to 17,000 miles per hour. ${ }^{94}$ Of the estimated $3,500,000$ objects that reside in outer space, only about 8,500 objects are currently trackable. ${ }^{95}$

Some experts believe that, even if mankind launched no new objects into orbit, the debris population would continue to increase exponentially and make at least parts of Earth orbit, such as LEO, unusable. ${ }^{96}$ The matter is serious, warranting the inclusion of the general topic of space debris being placed on the COPUOS agenda in the early 1990s out of concern for military and national security programs, as well as the costs of the removal of known debris.

\section{Professor Marietta Benkö notes:}

... problems resulting from the production of space debris do not only affect the (growing) number of space-faring nations, but also every single country and its inhabitants. Every day life world-wide depends significantly on space services. Let me just mention: phone, fax and online banking as well as the use of

\footnotetext{
${ }^{91}$ See J. R. Primack \& N. E. Abrams, Invited Talk at Conference on Science and the Search for Meaning: Star Wars Forever?-A Cosmic Perspective, $19 \quad$ April 2002, available at <http://0physics.ucsc.edu.library.newcastle.edu.au:80/cosmo/UNESCOr.pdf> (last visited on June 15, 2007).

92 Id.

${ }^{93}$ This means that debris orbiting approximately 800 kilometers above the Earth resulting from testing, deployment, and use of space assets (whether satellites or weapons) reside there for decades.

${ }^{94} I d$.

95 With current technology, computer models can only track space objects in LEO that are over ten centimeters in diameter and objects in GEO that are over one meter in diameter. See UN Comm. on the Peaceful Uses of Outer Space, Scientific and Technical Sum-Comm., Technical Report on Space Debris 25, UN Doc. A/AC.105/720 (1999); C. D. Williams, Space: The Cluttered Frontier, 60 JOURNAL OF AIR LAW AND COMMERCE 1139, $1141-1142$ (1995).

${ }^{96}$ Williams id., at 1146.
} 
the internet as a source of communication and information...Therefore civilians and the military have the same interest in keeping outer space 'clean' which makes the rational and prudent use of this environment an imperative in order to preserve its uses also for future generations. ${ }^{97}$

The continued collision of debris (which increases exponentially the more the debris) could eventually "produce so much dust that a lasting twilight will cast over the Earth, shrouding the planet in a haze of metallic pollution. ${ }^{98}$ The matter is accentuated further in the case of deliberate use of kinetic and hypervelocity weapons in space. Some scholars have emphasized that a war in space could create a battlefield that would last forever, with the capacity to encase the entire planet in a shell of whizzing debris, thus making space near the Earth highly hazardous for peaceful as well as military purposes. ${ }^{99}$ 'One of the most serious dangers posed by debris is the 'cascade effect' - a process by which space debris will become self-generating and therefore uncontrollable. ${ }^{100}$ The more space objects in orbit, the greater the probability that there will be a collision. With each new collision, there is a corresponding increase in the amount of debris, which would then result in an even greater probability of collisions. ${ }^{101}$ Professor Benkö cautions:

$\ldots$ it is established that [space debris] do not only pose a risk to space activities in the orbit where they were generated. For example, if an Earth orbit is polluted by a debris cloud (which is always spreading rapidly i.e. through the uncontrolled collision of the debris pieces with each other as well as explosions as a result of such collisions) access from the Earth to outer space can be in serious danger if space objects have to cross this orbit upon launch or re-entry. As a result such an orbit can have the effect of 'barbed wire' around the Earth. ${ }^{102}$

The use of international environmental law finds a base in the Space Law regime through several core provisions. The Liability Convention addresses State liability for activities in outer space. ${ }^{103}$

\footnotetext{
${ }^{97}$ Benkö, supra note 90 , at 160.

98 Scheetz, supra note 89 , at 70 .

${ }^{99}$ Id.

${ }^{100}$ Williams, supra 95, at 1145-1146.

${ }^{101} \mathrm{Id}$.

102 Benkö, supra 90, at 150.

103 Convention on International Liability for Damage Caused by Space Objects, opened for signature 29 March 1972, 961 UNTS 187; 24 UST at 239 (entered into force Sep. 1, 1972) at art. I.
} 
Article I(a) of the treaty defines 'damage' as 'loss of life, personal injury or other impairment of health; or loss of or damage to...property of international intergovernmental organizations. ${ }^{, 104}$ Turning to the Outer Space Treaty, Article VI provides that State Parties shall bear international responsibility for national activities in outer space, regardless of whether or not those activities are conducted by government or private entities. ${ }^{105}$ This provision arguably applies to space debris, because it results from States' activities in outer space. Of course this assertion is somewhat complicated by the lack of a uniform accepted legal definition of 'space debris' within the Space Law regime - a shortcoming that must ultimately be resolved. Further Article VII deals more specifically with liability of a State for damage to another State which is a party to the treaty, from the other State's space object or its components. ${ }^{106}$

In 2007, the Report of the Scientific and Technical Subcommittee of COPUOS expressed concern about the risk that the creation of space debris, intentional or otherwise, represented to human spaceflight, space infrastructure and space activities. ${ }^{107}$ Since outer space is the 'common heritage of all mankind', all countries have a right to provide input to the finalization of the policies and objectives of any organization affecting outer space, regardless of their level of involvement in space. Sustainable development provides a feasible international environmental avenue toward banning (all or at least most) space weapons and effectively accomplishing the central objectives of intergenerational equity. ${ }^{108}$ Considering that orbital debris is a serious

\footnotetext{
${ }^{104} I d$.

${ }^{105}$ Id. at art. VI.

106 Outer Space Treaty, supra note 27, at art. VII.

${ }^{107}$ United Nations A/AC.105/890 General Assembly Distr.: General 6 March 2007 Original: English Committee on the Peaceful Uses of Outer Space, Fiftieth session, Vienna, 6-15 June 2007. Report of the Scientific and Technical Subcommittee on its forty-fourth session, held in Vienna from 12 to 23 February 2007.

108 See E. Brown-Weiss, IN FAIRNESS TO FUTURE GENERATIONS: INTERNATIONAL LAW, COMMON PATRIMONY, AND INTERGENERATIONAL EQUITY (1989).
} 
consequence of space exploration and use, ${ }^{109}$ the vision and foresight of decades past must be revisited and revised to preserve and protect the environment of outer space.

\subsection{CONCLUSION}

Because of its uniquely commanding height, outer space has gained even greater military and strategic value in the post-cold-war international strategic environment. This provides for the possibility that outer space will become a platform for warfare. This development will only result in negative consequences. It will disrupt global strategic balances and stability, undermine international and national security and harm existing arms control arrangements, in particular those related to nuclear weapons and missiles. All of these will inexorably trigger a new arms race — the symptoms of which we are already witnessing.

In addition, the deployment and use of space weapons will seriously threaten the security of space assets and risks causing irreversible harm to the biosphere of the earth. A common sense approach will not unduly jeopardize the economic and strategic interests of those States utilizing space technology, but will make it clear that there are strict binding limits as to how far and for what purposes this technology can be implemented.

The international community should, ideally, not allow developing space warfare technologies to outpace the international space law regime. Even if this is not possible in every respect, the fluidity and flux of international politics ought to offer a strong reason for the United Nations to

\footnotetext{
${ }^{109}$ Majority of civilian and military telecommunication satellites are in GEO, along with many meteorological, broadcasting, data relay, tracking, and remote sensing satellites. The primary problems with debris generation in GEO are the limited number of available slots and the fact that, in GEO, objects that are not removed can have orbital lifetimes nearing ten million years. See H. A. Baker, SPACE DEBRIS: LEGAL AND POLICY IMPLICATION, 25-26 (1989).
} 
categorically deny each and every nation explicit or tacit permission to place weapons in outer space, since changing geopolitical dynamics will lead other aspiring space powers along the same path. In the absence of such action, there is an increasing likelihood that outer space will not only be used to facilitate armed conflict (as it already is) but will become a theatre of war. The tendency of the major militarized powers to rely ever increasingly on space technology is spiraling into a space weapons race. Even though the US may still claim space superiority, it can only be a matter of time before other space-faring countries - Russia, China and perhaps India will have developed equally sophisticated (and potentially devastating) space weapons technology.

This Article has indicated that, when the stark reality of space warfare dawns on humankind, there will be a serious legal deficit in the absence of specific international norms restricting the deployment of weapons in outer space. The risks that space warfare will become a reality necessitate the formulation of a new legal commitment in the international community, leading either to the conclusion of a treaty that comprehensively bans the deployment of weapons in outer space, or at the very least to the adoption of amendments to the Outer Space Treaty designed to clarify that 'peaceful' means precisely that, hence avoiding sophist arguments by space powers. Although the meaning of the phrase 'peaceful uses of outer space' has long defied specific definition, the dangers can be best addressed if parameters are established that bypass the sometimes conflicting self interests of space-faring powers, and once again focus on the 'collective humanity' principles of space law and the use and exploration of outer space. These goals no doubt confront very complex and traditional perceptions (among some States at least) of sovereignty, but in the end represent the most secure route towards the exploration and use of outer space. 
The space faring powers have repeatedly expressed a commitment to the exploration and use of outer space by all nations for peaceful purposes and for the benefit of all humanity. States should pursue greater levels of partnership and cooperation in national and international space activities and work together to ensure the continued exploration and use of outer space strictly for peaceful purposes. Prevention of an arms race in outer space should be actively advocated. We must move towards the negotiation of a comprehensive international legal instrument addressing issues of space weaponization, based on the accepted principle that space is the common heritage of mankind, The progress of human society will suffer should space — which offers so much to all of us as a catalyst for peaceful development and innovation — is be transformed into a military frontier. 